\title{
Primary breast lymphoma and MRI
}

\author{
N Pedana*, S Musella, D De Rienzo, C Viviano, D Rampone, G Confuorto \\ From de Senectute: Age and Health Forum \\ Catanzaro, Italy. 5-7 December 2009
}

\section{Background}

Primary lymphomas of the breast (PBNHL) are uncommon and exclusive to the elderly. Magnetic resonance imaging (MRI) features of these malignancies can be relevant in establishing the extent of the disease and planning the appropriate therapeutic strategy, usually represented by chemo-and radiotherapy, rather than surgery. The purpose of this study is to assess MRI features of PBNHL.

\section{Materials and methods}

MRI examination performed on four patients with known PBNHL were retrospectively evaluated.

Lesions were analysed for both morphology and kinetics.

\section{Results}

The mean MRI maximum diameter was $46 \mathrm{~mm}$ (range 12-69).

Three lesions showed a mass-like enhancement; one lesion showed a non mass-like enhancement.

For the mass-like lesions kinetic curve assessment of initial rise showed slow enhancement in one lesion, rapid enhancement in two lesions, and medium enhancement in one lesion.

Assessment of delayed enhancement showed plateau in 3 lesions and washout in one lesion.

\section{Conclusions}

MRI features of primary breast lymphomas in this study cohort suggest that the occurrence of a PBNHL should be considered in the presence of large enhancing lesions of the breast, especially if associated whit skin thickening. MRI may also have an important role in the assessment of response to therapy and diagnosis of recurrence.

Department of Surgical Oncology (Castel Volturno ) Caserta, Italy
Published: 19 May 2010

doi:10.1186/1471-2318-10-S1-A22

Cite this article as: Pedana et al:: Primary breast lymphoma and MRI.

BMC Geriatrics 2010 10(Suppl 1):A22.
Submit your next manuscript to BioMed Central and take full advantage of:

- Convenient online submission

- Thorough peer review

- No space constraints or color figure charges

- Immediate publication on acceptance

- Inclusion in PubMed, CAS, Scopus and Google Scholar

- Research which is freely available for redistribution

Submit your manuscript at www.biomedcentral.com/submit
C Biomed Central 